\title{
Assessment Of The Implementation Of The Reading Component Of The English Language Curriculum For Basic Education In Nigeria
}

\author{
Hanna Onyi Yusuf \\ Department of Educational Foundation And Curriculum \\ Faculty of Education Ahmadu Bello University \\ Zaria, Nigeria \\ E-mail: hannayusuf@yahoo.com
}

Doi:10.7575/aiac.alls.v.5n.2p.96

URL: http://dx.doi.org/10.7575/aiac.alls.v.5n.2p.96
Received: 17/02/2014

Accepted: 03/04/2014

\begin{abstract}
This study assessed the implementation of the reading component of the Junior Secondary School English Language Curriculum for Basic Education in Nigeria. Ten (10) randomly selected public and private secondary schools from Kaduna metropolis in Kaduna State of Nigeria were used for the study. Among the factors assessed in relation to the implementation of the curriculum were: teachers variation of methods and the differences between school types in the implementation of reading component of the English Language curriculum. Thirty (30) English language teachers were involved in the study. Questionnaire and observation were the instruments used in gathering data. The data were analyzed, using frequencies, percentages, means and standard deviation. The analysis of the data collected revealed that there was no significant difference in the implementation of the reading component of the English language curriculum in public and private schools. Teachers in both schools tended to have the same pattern of implementing the reading component of the English language curriculum. It was observed that the implementation of the reading component of the English language curriculum was not very effective from the classroom observation of the teachers. Teaching was teacher-centred. Students were passive and did not participate in class discussion. It was recommended that teachers should adopt learner centred approaches in teaching reading and students should be encouraged to participate actively in class discussions. For efficiency and effectiveness of the implementation of the reading component of the English curriculum, there should be continuity of the syllabus (from JS 1-3) and there should be checks and balances to ensure the successful delivery of the curriculum.
\end{abstract}

Keywords: assessment, reading, education in Nigeria

\section{Introduction/Background to the Study}

Curriculum, which is generally viewed as the guiding principle for teachers at different levels, has sometimes been misconstrued, misinterpreted and/or "poorly implemented due to teachers' lack of the required skills to teach effectively, inadequate comprehension of the curriculum, misinterpretation of its contents, and so on. From observation, English curricula are not readily available in some schools and inaccessible to the teachers in others. Some of these factors coupled with the inadequacies of the curriculum seem to affect the teachers' implementation efforts negatively. On the other hand, funds for purchasing materials and for organizing induction courses in schools are not readily available. Lack of funds can lead to inadequacy of teaching aids and demoralization of the morale of enthusiastic teachers. Even when all of these are in place, teachers may still lack the required skills to teach effectively.

The quality of the reading component of the Junior Secondary (JS) JSS English curriculum, its implementation and the impact on the development of Junior Secondary School students has been agitating the inquisitive minds of many scholars. There are doubts in some quarters about the qualifications of the English language teachers who are expected to implement the curriculum (Adeyanju, 1981, Aukerman, 1986). Perceived teachers' inefficiency and poor performance of students are symptomic of poor interpretation and implementation of the curriculum.

This researcher has observed that there are no stimulating learning environments for some junior secondary schools in Kaduna metropolis. Students learn under trees in some schools, while in others, classes are without some basic and sufficient learning facilities such as chairs, desks, chalkboard etc. Some have over populated classes and lack adequate teaching materials/aids. All these factors coupled with poor conditions of service can affect the smooth implementation of the curriculum. this study is aimed at finding out the methods teachers use in implementing the reading component of the English language curriculum and the differences between school types in the implementation of the reading component of the English language curriculum.

\section{Purpose of the Study}

The study sets out:

i. to find out the methods used in the teaching of the reading component of the Junior Secondary School English Language curriculum, 
ii. to determine the difference between school types in the implementation of the Reading component of the English language curriculum.

\section{Research Questions}

This research sought to answer the following questions:

1. What are the different methods used by teachers in the implementation of the reading component of the Junior Secondary School English language Curriculum?

2. What are the differences between school types in the implementation of the reading component of the Junior Secondary School English Language Curriculum?

\section{Review of Related Literature}

The guideline on the FME Junior Secondary School English language curriculum stipulates that teachers' attitudes are important in the learning process. Methods vary and materials are determined by academic and professional preparations. Etim (1981) analyzed what teachers of English should do as follows: provide necessary background experience, use the right method of instruction and materials to develop student interests and motivate them.

In curriculum implementation, the most important single determinant of what takes place in JSS English language classroom is the teacher, whose lesson notes, management of curriculum, sophistication and appropriation of teaching aids which are subsumed in transactional skills are the function of training, experience and natural flair. Ability to communicate effectively will also depend on interpersonal participation in the class, clubs etc. Bamgbose (1991) sees curriculum implementation as ranging from actual language work to production of materials.

Carlson (2005) views curriculum implementation as developing a plan, getting everything in place, and fine tuning of the programme to better meet the needs of the learner. Yunusa (2002) is of the opinion that curriculum implementation involves steps taken to attain the set educational goals.

All of the definitions given above point to the fact that for proper implementation of the curriculum, there must be learners, teachers, and learning materials, all of which work hand in hand to achieve the goals set by curriculum planners. Full implementation of the curriculum demands that the teacher must be trained to experiment and manipulate the curriculum since by implication, the teacher is the most important part of the JSS English language curriculum.

Some reading specialists and curriculum experts believe that reading is a matter of maturation rather than a process developed through systematic instruction and practice. Some see reading as primarily a visual task, studied and developed through the use of mechanical device that records eye movements and increases reading speed, by expanding eye span intake of printed symbols, Aukerman (1989). One of the tasks that confronts the secondary school teacher of JSS English is how to train students to become good readers. This is informed by the fact that students might have been unfortunate to be badly taught reading skills at the early stage. McGregor (1987) says reading aloud from textbook in turns while others listen, makes students to listen to mistakes and learn how to read badly. Other wrong approaches while reading are: pointing with fingers at words, moving the heads, and also moving their lips. These act as constraints to effective reading. To teach students who already have these wrong reading habits is a demanding task for the teacher who is faced with the primary responsibility of inculcating and teaching good reading skills (Balogun, 1995, Umerah, 2009). How accurate are the JSS teachers in observing the above anomalies in the process of the interpretation and implementation of the reading component of the JSS English curriculum in schools in Kaduna metropolis requires empirical evidence which this study seeks to provide.

According to (Abiri, 1985) primary school teachers, including the professionally trained ones, have had little or no guidance in the teaching of the reading component of the English language curriculum. The view is confirmed in Unoh's (1985) observation that 'There is the problem of inadequate teachers of reading in some schools. How far this situation is applicable to schools in Kaduna metropolis is an issue of great contention that yeans for verification.

Researchers (Oyetunde, 2009, Yusuf 2011, Olaofe, 2013) have revealed that Nigerian students have various reading problems. Part of the reason for this inefficiency is attributed to the students and a greater part to the methods being adopted by teachers in teaching reading. Taiwo (1980) feels that poor rate of reading and general apathy for written texts, make students inefficient readers. In JSS English language curriculum, students learn how to read and to discover their own motivation toward reading by practising. This discovery helps the teacher to design appropriate teaching methods and reading materials for students.

\section{Methodology}

Survey research design was used for the study. Questionnaires were administered to the teachers so as to harness their opinions on how the Reading component of the JSS English language curriculum is implemented by them and the various methods used in implementing the curriculum. The administration of the teachers' questionnaire was executed by the researcher with the help of research assistants. Likert rating scale was used for scoring responses on the questionnaire.

In addition to the use of questionnaires, the teachers and students were observed while teaching and learning were going on. The following aspects were observed content, teachers' activities, students' activities/participation as a way of 
evaluating the effectiveness of teachers implementation. Teaching aids/methods used, teacher's objective and the extent of curriculum coverage were equally observed while teaching was taking place.

Stratified random sampling procedure was used in obtaining data for this study. A sample of ten (10) schools was drawn randomly out of three hundred and eighty four (384) schools with a population of 10,060 students. All the schools in Kaduna Metropolis cannot be used as it would be cumbersome to obtain information by census of the entire population. The schools used for this study are listed in the appendix. An aggregate of thirty teachers (i.e three from each school) were selected randomly from ten schools for the study.

The data collected for the research was analyzed using frequencies and percentages.

\section{Data Analysis/Discussion}

Research Question 1: what are the different methods used by teachers in the implementation of the reading component of the Junior Secondary School English language curriculum?

This question was assessed using teachers' opinion on the methods used in the implementation of the reading component of the English language curriculum in Junior Secondary Schools. $90 \%$ of the teachers said they do not have specific methods of teaching reading. $10.0 \%$ of the teachers claimed that they use the vocabulary method to teach reading. However, all the teachers agreed that there were some levels of difficulties being encountered in the implementation of the reading component of the English language curriculum.

Table 1. Frequency of teaching reading in the selected schools

\begin{tabular}{lc}
\hline $\begin{array}{c}\text { Frequency of teaching the component of the English } \\
\text { language curriculum }\end{array}$ & Reading \\
\hline & Frequency (\%) \\
Everyday & $15(50)$ \\
Twice a week & $9(30)$ \\
Once a week & $3(10)$ \\
Once a month & $3(10)$ \\
Total & $30(100)$ \\
\hline
\end{tabular}

Table 1 revealed that reading skill was almost an every day affair in all the selected schools. At least $50.0 \%$ of the teachers claimed to practise the skill in their teaching and learning of the English language in the selected schools, while $30.0 \%$ of the teachers were of the opinion that the practice of the skill was only conducted two times in a week in their respective schools. Only $10.0 \%$ of the teachers claimed conducting the skill once a week and once a month respectively. Techniques used in the teaching and learning of the reading skill included intensive and extensive reading by the students for details and the gists of the passages respectively. The observed implementation levels of the reading component of the curriculum were assessed on a four point Likert scale. These were Very well (VW) implemented, Well (W) implemented, poorly implemented (P) and very poorly (VP) implemented.

Table 2. Observed level of implementation of the reading component of the English language curriculum

\begin{tabular}{llllll}
\hline & \multicolumn{1}{c}{ Implementation } & VW & W & P \\
\hline 1 & Reading for main ideas & 11 & 18 & 1 & - \\
& & $(36.7)$ & $(60.0)$ & $(3.3)$ & \\
2 & Reading to grasp word & 12 & 13 & 5 & \\
& meaning & $(40.0)$ & $43.3)$ & $(16.7)$ & \\
3 & Reading to answer & 16 & 8 & 6 & - \\
& specific questions & $(53.3)$ & $(26.7)$ & $(20.0)$ & \\
& Reading for implied & 4 & 12 & 12 & 2 \\
& meaning & $(13.3)$ & $(40.0)$ & $(40.0)$ & $(6.7)$ \\
& Reading for gist & 6 & 14 & 8 & 2 \\
& & $(20.0)$ & $(46.7)$ & $(26.7)$ & $(6.7)$ \\
\hline
\end{tabular}




\begin{tabular}{llllll}
\hline \multicolumn{1}{c}{ Implementation } & \multicolumn{1}{c}{ VW } & W & P & VP \\
\hline 6 & 2 & 6 & 15 & 7 \\
& & $(6.7)$ & $(20.0)$ & $(50.0)$ & $(23.3)$ \\
& $\begin{array}{l}\text { Reading for } \\
\text { relationship of thought }\end{array}$ & & & & \\
Reading for details & 6 & 14 & 8 & 2 \\
8 & $(20.0)$ & $(46.7)$ & $(26.7)$ & $(6.7)$ \\
& $\begin{array}{l}\text { Reading for required } \\
\text { information }\end{array}$ & 8 & 12 & 10 & - \\
\hline
\end{tabular}

Most teachers as indicated in the table did not have much difficulty in implementing reading for main ideas, word, meaning, details and required information. However, most teachers had difficulty in teaching reading for implied information and reading for relationship of thought.

Research Question 2: what are the differences between school types in the implementation of the Reading component of the Junior Secondary School English language curriculum?

Table 3 presents the frequency of teaching reading by type of school (Public and private) and the methods used in the implementation of the curriculum. The teachers were scored based on percentages for this question because of the unequal number of their representation from the different types of schools.

Table 3. Frequency of teaching the Reading component of the English language curriculum by school type

\begin{tabular}{ccc}
\hline $\begin{array}{c}\text { Frequency of teaching } \\
\text { reading }\end{array}$ & Public school & Private school \\
\hline & $\%$ & $\%$ \\
Everyday & 30 & 60 \\
Twice a week & 40 & 30 \\
Once a week & 20 & 10 \\
Once a month & 10 & - \\
Total & 100 & 100 \\
\hline
\end{tabular}

Table 3 revealed that the private school gave more attention to the implementation of the Reading component of the English language curriculum than was obtained in the public schools. For example, in the teaching of reading skill, $60.0 \%$ of the teachers in private schools claimed to conduct reading skill, teaching every school day while the equivalent number of teachers in the public schools was $30.0 \%$.

However, the methods used in the teaching of the skill Reading did not seem to have differed much, as teachers in both schools claimed to have intensive and extensive reading by the students and aiming to get the gist of the passage as well as the implied meaning and the required information from such texts.

The classroom observation of the actual implementation of the Reading component of the English language curriculum is presented in Table 4. The scores in the table were converted into percentages to enable even comparison of the actual implementation of the curriculum in the selected schools.

Table 4. Observed level of implementation of the Reading component of the English language curriculum

\begin{tabular}{|c|c|c|c|c|c|c|c|c|c|}
\hline 1 & Reading for main ideas & 36.7 & 60.0 & 3.3 & - & 20 & 47 & 10 & 23 \\
\hline 2 & $\begin{array}{l}\text { Reading to grasp word } \\
\text { meaning }\end{array}$ & 40.0 & 43.3 & 16.7 & - & 30 & 50 & 13 & 7 \\
\hline 3 & $\begin{array}{l}\text { Reading to answer } \\
\text { specific questions }\end{array}$ & 53.3 & 26.7 & 20.0 & - & 3 & 53 & 27 & 17 \\
\hline 4 & $\begin{array}{l}\text { Reading for implied } \\
\text { meaning }\end{array}$ & 13.3 & 40.0 & 40.0 & 6.7 & 27 & 33 & 30 & 10 \\
\hline 5 & Reading for gist & 20.0 & 46.7 & 26.7 & 6.7 & 20 & 30 & 50 & 0 \\
\hline & Reading for relationship & & & & & 23 & 40 & 27 & 10 \\
\hline
\end{tabular}


of thought

6

7

Reading for details

Reading for required

information $\begin{array}{llll}6.7 & 20.0 & 50.0 & 23.3\end{array}$

$\begin{array}{llll}20.0 & 46.7 & 26.7 & 6.7\end{array}$

27

40
33

30
33

20
7

10

Table 4 revealed that most teachers were generally good in the teaching of reading skills as indicated in items 1 and 2 of the table. As observed in the lessons, most teachers in the private and public schools were able to teach the aspect of reading for main ideas, reading to grasp words' meaning, reading to answer specific questions and reading for implied meaning as parts of the reading skill. As indicated in items 5 to 8 in the table, teachers in both schools were not good at teaching reading for gist, reading for relationship of thought, reading for details and reading for required information as parts of the reading skill.

\section{Conclusion}

From the analysis of the data collected for this study, it was observed that English language teachers in the selected junior secondary school within Kaduna Metropolis had the knowledge of the skills involved in the teaching of the Reading component of the English language curriculum. In the process of implementing the reading component of the English language curriculum, emphasis was discovered to be tilted toward reading for main ideas rather than reading for implied meaning. Reading for relationship of thought was poorly implemented. Reading component of the English language curriculum in the selected schools was not very effective from the classroom observation of the teachers. This observation was common in both private and public schools. What was responsible for this as observed by this researcher are the methods used by the teachers. Most teachers do not use the student-centred approach or method and hardly vary their methods of teaching for effective understanding and effective curriculum implementation. Variety they say, is the spice of life. Teachers should be encouraged to vary their methods by using approaches that are interactive learner centred and participatory to enhance the development of good reading skills.

\subsection{Recommendations}

The following recommendations were made based on the findings of this study:

1. Time table in all schools should reflect the teaching of the Reading component of the English language curriculum. This can be either twice or thrice in a week. Principals, heads of department should ensure that these activities are religiously carried out.

2. It would not be out of place to recommend that recruitment of English language teachers should be based on professional qualification. Additional qualification such as training in teaching reading should be considered as an added advantage.

3. Schools should invite reading experts once in a while to assist in teaching difficult areas (such as reading for implied meaning and reading for relationship thought) of the Reading component of the English curriculum for effective implementation.

4. All English Language teachers should be encouraged to become members and of the Reading Association of Nigeria and International Reading Association. They should also be encouraged to attend workshops/seminars/conferences organized by these associations regularly in order to be acquainted with the various techniques and strategies for teaching reading and to keep abreast of the current innovations in the field.

5. For efficiency and effectiveness of the implementation of Reading components of the English Language curriculum, there should be continuity, of the syllabus (from JS 1 - JS 3) and there should be checks and balances to ensure that the curriculum is faithfully delivered.

6. Teachers should adopt, learner centred approaches to teaching reading where emphasis is more on students active participation in class activities. More emphasis should be placed on doing, role play, story telling, songs stimulation and dramatization. In addition to this, students should be encouraged to read newspapers, novels, magazines, etc to improve on their reading fluency.

\section{References}

Abiri J. O (1985) Literacy and Reading in Nigeria, Problems and Method of Teaching initial reading in English and Nigeria languages Unoh, Omojuwa and Crow (Eds).Mc Milan, Lagos.

Adeyanju, T.K (1981) English in the JSS Curriculum: its subject, medium and practical function: the state of art. University of lagos press Lagos.

Aukerman, R (1989). Approaches to beginning Reading John Wiley \& Sons, New 
Aukerrnan, I. L (1986). The junior Secondary School System; Prospect and problems. Nigeria journal of curriculum studies University Press Lagos.

Balogun, B (1995). The Relationship between language and Reading in Nigeria' in Gilliland J (ed 1977).Ibadan Nigeria.

Bamgboye (1991) Language and the Nation, George Square, Edinburgh.

Carlson, M. (2005) Teachers and English as a second language; Cambridge University.

Etim, J. S (1985). Literacy and reading in Nigeria Vol. 2 A.B.U Zaria. Nigeria

McGregor, G. P (1987) The process of curriculum, Pedaogic Europaea, 1970/71,

Olaofe, I.A (2013). "Teaching English in Second Language Adverse situations A Solution - based Approach”. Zaria: Applied Linguistics and language Education Centre. Yahaya ventures.

Oyetunde T.O (2009). "Beginning Reading Scheme" Empowering teachers to help their pupils become good teachers. Jos: LECAPS publishers. Shertogenboch.

Taiwo (1980) Mother Tongue or Second Language on teaching of Reading in Multilingual societies: Copying International Reading Association, Longman Ibadan.

Umerah, M.O (2009) Assessment of the Implementation of the Junior Secondary School English language curriculum in selected schools in Kaduna metropolis. Unpublished M.Ed thesis, Ahmadu Bello University, Zaria.

Unoh, S.O. (1983) Reading Improvement in Nigeria as a Multilingual Nation: Problems and Prospects. In Literacy and Reading in Nigeria, Vol. 1, Zaria: Institute of Education, ABU Zaria.York.

Yunusa, M. B (2002) - Issues on curriculum Department of Education Ahmadu Bello University Zaria ABU Press

Yusuf H.O (2005) A comparative study of the effectiveness of language development and vocabulary methods in teaching reading comprehension Unpublished $\mathrm{Ph}, \mathrm{D}$ Dissertation, University of Abuja, Abuja

Yusuf, H.O. (2011). "Towards Improvement in the teaching of reading comprehension in primary schools: the need to activate pupils' relevant schema”. Theory and practice in language studies Vol 1 (1) January 2011. Pp 16-20 Academy Publishers.

Yusuf, H.O. (2012). Fundamentals of Curriculum and Instruction. Kaduna: Joyce Publishers.

\section{APPENDIX I}

Table 3. Names of ten schools and number of students

Name of Schools

G.G.S.S Kawo(JSS English students)

Clara Secondary School Kawo

SMC Angwar Dosa (JSS English Students)

Hampos College

Technical college Malali

Dambo International School

Rimi College

Jenie secondary school, Barnawa

GGSS Tafawa Balewa college

\begin{tabular}{llll}
\hline populati & Male & Female & Total
\end{tabular}

on

$$
500
$$

30

450

550

510

500

570

480

30

520

50

490

30

430

20

50

50

Sample size.

Grand Total

5000

280

Source: Ministry of Education, Kaduna 


\section{QUESTIONAIRE FOR TEACHERS OF ENGLISH LANGUAGE IN JUNIOR SECONDARY SCHOOLS IN KADUNA METROPOLIS}

\section{SECTION A}

BACKGROUND INFORMATION OR DEMOGRAPHIC DATA

1. Name of school

2. School type Public $\square$ Private $\square$

3. Teaching qualification(s)

4. How often do you teach the reading component of the English Language Curriculum?
A. Everyday
B. Twice a week
C. Once a week
D. Once a month

Implementation

\begin{tabular}{|l|l|l|l|l|}
\hline READING & $\begin{array}{c}\text { Very well } \\
\text { Implemented }\end{array}$ & Well Implemented & $\begin{array}{c}\text { Poorly } \\
\text { Implement }\end{array}$ & $\begin{array}{c}\text { Very Poorly } \\
\text { Implement }\end{array}$ \\
\hline Reading for main ideas & & & & \\
\hline $\begin{array}{l}\text { Reading to grasp word } \\
\text { meaning }\end{array}$ & & & & \\
\hline $\begin{array}{l}\text { Reading to answer specific } \\
\text { questions }\end{array}$ & & & & \\
\hline Reading for implied meaning & & & & \\
\hline Reading for gist & & & & \\
\hline $\begin{array}{l}\text { Reading for relationship of } \\
\text { thought }\end{array}$ & & & & \\
\hline Reading for details & & & & \\
\hline $\begin{array}{l}\text { Reading for required } \\
\text { information }\end{array}$ & & & & \\
\hline
\end{tabular}

APPENDIX III

Observation Checklist

\begin{tabular}{|c|c|c|c|c|c|}
\hline Observed Items & V. good & Good & Poor & V. poor & Total \\
\hline Neatness & & & & & \\
\hline Ability to motivate students & & & & & \\
\hline Quality of lesson notes & & & & & \\
\hline Content/Topic & & & & & \\
\hline Objectives & & & & & \\
\hline Methods & & & & & \\
\hline $\begin{array}{l}\text { Teaching aids/Instructional } \\
\text { Materials }\end{array}$ & & & & & \\
\hline Teacher/students Relationship & & & & & \\
\hline Students activities & & & & & \\
\hline
\end{tabular}

